\title{
Seeing the Spatial Readiness of Central Kalimantan as a Candidate for the Capital City Before the Decision of East Kalimantan as the New Capital
}

\author{
Imam Qalyubi ${ }^{1}$, Abdul Qodir $^{2}$, Abubakar $^{3}$, Misrita $^{4}$ \\ \{Imamqalyubi@yahoo.com\} \\ ${ }^{123}$ State Islamic Institute (IAIN) Palangka Raya, Central Kalimantan, Indonesia \\ ${ }^{4}$ University of Palangka Raya, Central Kalimantan, Indonesia
}

\begin{abstract}
This paper presenting and exploring the data about the readiness of Central Kalimantan as candidates for capital city before the establishment of East Kalimantan as a new capital. This type of research is descriptive qualitative using interview and documentation methods. The findings of the research from the three regions studied are the municipalities of Palangka Raya, Katingan Regency and Gunung Mas Regency that the three regions have made some preparations in responding to the discourse of moving the capital as did the city of Palangka Raya in the form of building road expansion, expansion and renovation of city parks and expansion Airport area. While the Katingan district, is preparing candidates for airports, ports and areas of forest conservation, production forests, agriculture and offices. The same thing is also done by Gunung Mas who has poured in the regional spatial plan for 2014 - 2034, it can be said that the availability of land for the construction of office infrastructure and other development areas has shown adequate readiness and can meet the expectations of the community in service development, so that the availability of the land meets the expectations and discourse of moving the capital of the Republic of Indonesia to Gunung Mas Regency, Central Kalimantan.
\end{abstract}

Keywords: Spatial planning, displacement, national capital, Central Kalimantan

\section{Introduction}

On August 26, 2019 The President of Indonesian Republic, Jokowi has officially announced that the capital city will be moved to East Kalimantan. However, prior to the decision, several regions, one of which was Central Kalimantan, was busy preparing as a candidate for the nation's capital.

If viewed in a variety of reports in Central Kalimantan, including the most often heard as a candidate for a new capital because it is considered to have various advantages such as wide area, geographical location, geographical position, not in the earthquake zone and other advantages. [1], [2], [3] However, East Kalimantan also has advantages that Central Kalimantan does not have, including airports that have been connected with several countries, as well as large ports that have existed and existed since the Dutch colonial era and several 
other advantages. If examined from the historical aspects of the discourse of moving the capital from Jakarta to Palangka Raya is not a new issue but has been done in previous periods. In various documents that the discourse of moving the capital has existed since the initial formation of the city of Palangka Raya into a province on July 17, 1957 as the 17th province. In several records it was said that the Indonesian Proclaimer at the time had given a statement "Make the city of Palangka Raya a capital and model," said the Proclaimer when he first planted a milestone in the development of the city of Palangka Raya. The words of the father of the proclamator were interpreted by the people, especially the people of Central Kalimantan as a code that Palangka Raya would be used as the new capital region. [4]

Although the two regions have their respective advantages, there are several things, but the decision remains in the hands of the president based on certain considerations that are closed because it is related to the stability of the country.

\section{Research Method}

The research carried out in this case is trying to present some data related to spatial preparation in three regions, namely Palangka Raya Municipality, Katingan Regency and Gunung Mas Regency in preparing themselves as the new capital detention area before the establishment of East Kalimantan as the new state capital.

This type of research is descriptive qualitative method. Descriptive research tends to be done by answering questions about the state of an object or subject of detailed observation. While qualitative research is characterized by data collection that is inductive or from data obtained in stages from small amounts to large quantities and ends with findings and conclusions. [5], [6]. Associated with data collection Herdiansyah mentioned that qualitative data collection methods tend to be flexible when compared with quantitative methods, meaning that loading and unloading data collection methods in qualitative research is permitted as an effort to adjust to the context in the field. [7], [8] In this research there are two data collection technic used: documentation study and interview. Documentation was first carried out in the preparation of this study in the form of documents such as manuscripts, books and articles. The next data collection is an interview that is collecting data through a questioning process involving two parties with the intention of digging up the data as stated by Gorden in Herdiansyah that the interview is "interviewing is a conversation between two people in which one person tries to direct the conversation to obtain information for some specific purpose ". [7]

\section{Results And Discussion}

\subsection{Palangka Raya City}

Basically, spatial readiness in the Palangka Raya city area is not independent, it is interrelated with other regions. The use of the term city of Palangka Raya in the context of the discourse of moving the capital is actually more accurately referred to as Central Kalimantan. For readiness as an area prepared as a candidate for the capital city of Palangka Raya, the government continues to improve, as has been done by the current mayor, Riban Satya, who has expanded the area around the Soekarno stake. It is also part of the preparation in 
responding to the discourse of moving the country's capital from Jakarta to the city of Palangka Raya.

Related to the area that will be made as the Capital City area of Palangka Raya city, in particular, has made a fairly comprehensive mapping, for example making a map of the allocation of the capital of the government based on the Decree of the Minister of Forestry 529 TH, 2012 on the function of the area in Central Kalimantan Province with an area of $775,701.18$ hectares. To see the following clearly map the area of the intended candidate capital. See [9]

Map of Government Capital Allocation Planning Based on Minister of Forestry's Decree $529 \mathrm{TH}, 2012$ concerning the Function of Regions in Central Kalimantan Province with an Area of $775,701.18$ Hectares.

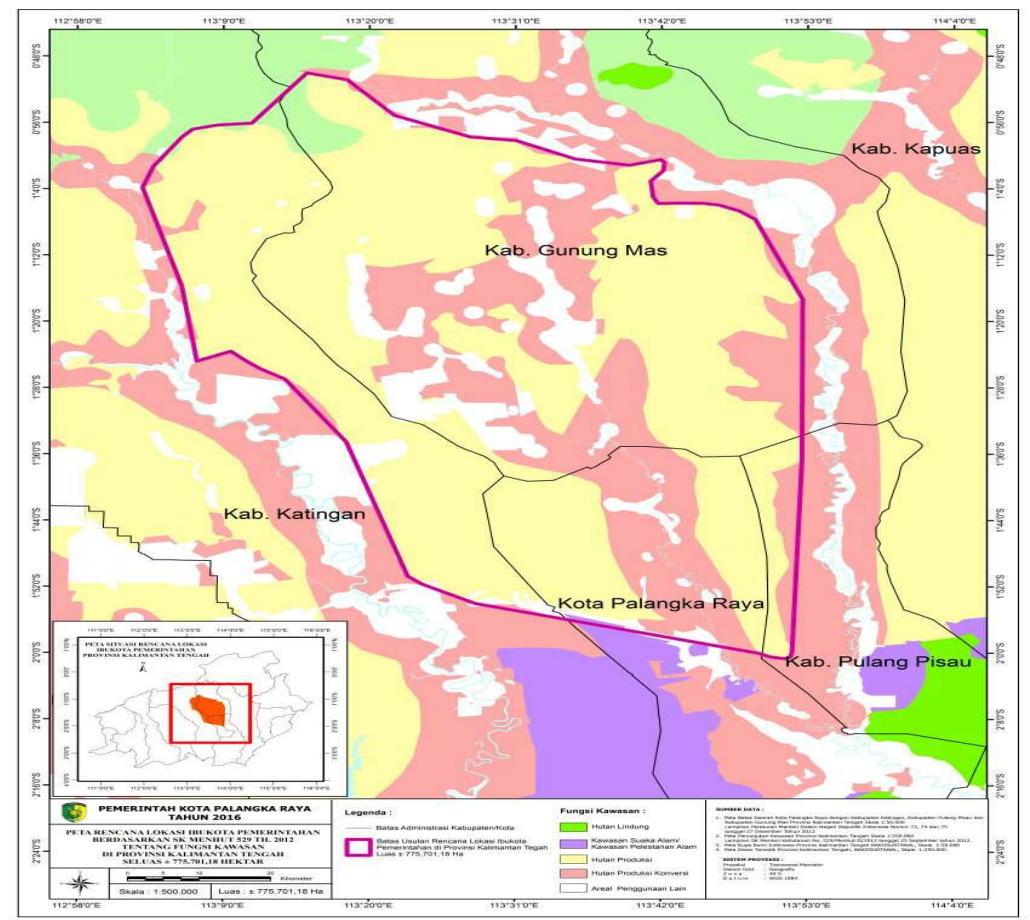

\subsection{Katingan Regency}

If referring to the data obtained in the Katingan area in the discourse of moving the capital from Jakarta to the city of Palangka Raya is very responsive, this can be seen from various forms of spatial readiness as outlined in some careful planning. From the data obtained by researchers in the field, there are several designs related to the candidates for the country's capital that have been prepared during the Katingan administration headed by H. Achmad Yantengli. Some of the spatial planning drawings of the capital candidates, especially those related to the Katingan district area, are in a soft file with the name "Capital Documents".

The serious effort of the Katingan district government as one part of the country's capital region can be seen in the capital documents mentioned above. The capital document explains several things that will be explained in part in this discussion such as the map of the 
candidates for the National Capital Airport which is placed in the Pagatan area of Katingan Regency with an area of 18,500,000 hectares.

In the following data there is a map of the development plan of the capital city of the Republic of Indonesia in Central Kalimantan, especially those included in the Katingan Regency. More details can be seen in the map below.

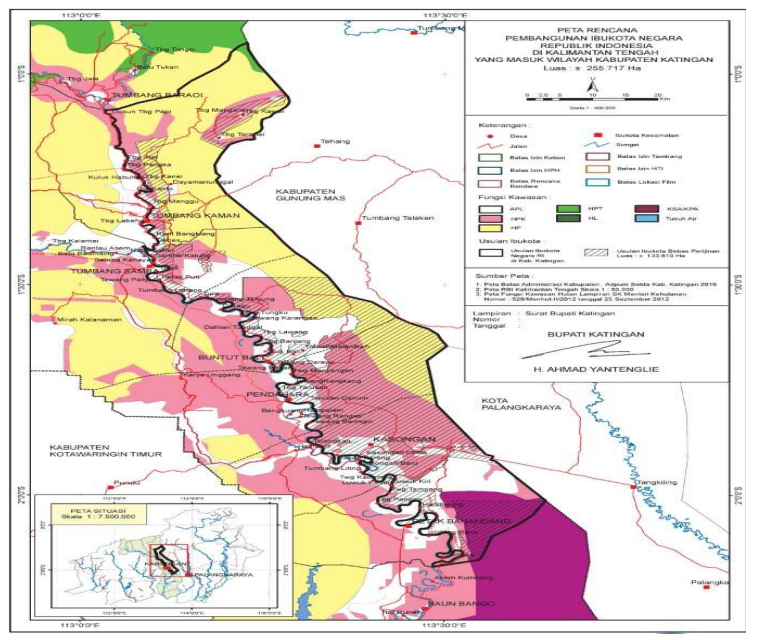

If the data above explains in detail related to the preparation of spatial airports, the road infrastructure in the next data or map will be expanded to only map the development plan of the capital city of the Republic of Indonesia in Central Kalimantan, especially those included in the Katingan district region and next is the map delineation plan the capital city which is a comprehensive map related to all spatial plans in the Katingan district, especially those relating to the region as part of the state capital candidate.

The selection of a capital city that does not have sea access is certainly risky. Sea access. Palangkaraya is not strategic enough. Sea access is important to be used as a means of supporting government. Indonesia is very fortunate because all provincial divisions always have sea access. In a development study, the geography of a country that has no sea boundary or landlock has proven to be a serious obstacle to its development. The most backward African countries, always occur in this geographical condition. In addition, Sukarno's attempt to plant a pole in Pahandut in 1957 was never followed by a systematic effort to make it a national capital. There is no need to wait to become the capital, just at this time, the area around a large roundabout starts to become congested and congested on Sunday night.

The Central Kalimantan region has the characteristics as intended in the various policy products, namely the vast land area and most of it is still forest, the territorial waters consisting of river and sea areas and the airspace above it. As a regional unit, the first step in spatial planning and territory is to analyze and identify the various characteristics of the space and region. This is to guarantee an area whose development direction remains environmentally oriented, constructive and planned structuring to analysis of regional development for the long term. See [10] 


\subsection{Gunung Mas Regency}

Based on Gunung Mas Regional Regulation No. 8 of 2014, regarding the Spatial Planning of Gunung Regency in 2014 - 2034. Whereas the plan for the Gunung Mas Regional Spatial pattern covers protected forest and cultivation areas.

The Protected Forest Area with an area of approximately 59,514.03 hectares includes: Damang Batu District, Miri Manasa District and Kahayan Utara Upper District.Cultivation Area, including: production forest allotment area, agricultural allotment area, mining demolition area, residential allotment area, industrial allotment area, tourist allotment area and other allotment area, see [11].

If related to the Spatial Plan contained in the Gunung Mas Regency Spatial Planning Year 2014 - 2034, it can be said that the availability of land for the construction of office infrastructure and other development areas has shown sufficient readiness and can meet the expectations of the community in service development, so that the availability of the land meets the expectations and discourse of moving the capital of the Republic of Indonesia to Gunung Mas Regency, Central Kalimantan. However, the involvement of all elements of the community in participating in building Central Kalimantan and Indonesia as part of devotion to the Nation and the State. Therefore, the expected success will be achieved when togetherness is built synergistically for the present and future.

Regulation on spatial planning has been regulated in several Regional Regulation rules in article 73 covering various kinds of community rights, compare [12]. the role of the community in spatial planning is regulated in article 74 , The role of the community in spatial use, The role of the community in controlling spatial use includes: (a ) providing input related to directives and / or zoning regulations, (b) participation in monitoring and overseeing the implementation of spatial plans that have been determined and thereafter. The procedures for the role of the community in spatial planning are regulated in article 76 , including: submitting input on the direction of development, potential and problems, formulation of draft / spatial planning through communication media / meeting forums; cooperating in spatial planning in accordance with statutory provisions etc.

Thus the regulations that have been established in the form of Gunung Mas District Regulation have protected the interests of the community as a whole, so there is no concern if violations are committed by relate parties, both the Government and the community, then it must return to the provisions set out in The Regional Regulation, see [13]. Awareness of implementing regulations will have a positive impact on the implementation of planned and programmed development both now and in the future.

\section{Conclusion}

In the aspect of spatial readiness in three regions, among others, the Municipality of Palangka Raya, Katingan Regency and Gunung Mas Regency. For the Palangkaraya region, readiness as one of the prospective regions of the country's capital has done several works such as road expansion. City parks and airport area expansion, although so far, are still inadequate despite plans that Palngka Raya airport will be moved to Katingan district.

Preparation of spatial planning in Katingan Regency has so far carried out several developments and certainly requires massive development to be made part of the capital because most of the area is still forested. Katingan is the largest rattan producer in Indonesia. Until this moment the Katingan district does not have an airport. The assessment of capital 
transfer planning is likely to include deciding whether Tjilik Riwut airport will be moved to Katingan district, or Tjilik Riwut airport will continue to operate by upgrading and building a new additional airport in Katingan district. Likewise, the municipality of Palangka Raya, Katingan Regency, Gunung Mas Regency has also prepared candidates for the capital region. Some areas that have been prepared include other areas: forest conservation areas, production forest areas, agricultural areas and pilot areas. However, there is a need for large financing because we know that the region is a mountain and hill region and frequent floods [14].

\section{Acknowledgements}

I would like to express my gratitude to the institution the State of Islamic Institute (IAIN) Palangka Raya, Central Kalimantan which has given the oppurtunity to me to conduct this research. My gratefull also dedicated Prof. Dr. Suwardi Endraswara, M. Pd. and Assoc. Prof. Rahimah A. Hamid, Ph.D as the reviewer and who have also given alot of critics and suggestion for the perfectness of this article. The last, this research is dedicated specifically to Dayak people in Central Kalimantan who have strugled in maintaining their culture.

\section{References}

[1] A. S. Nursyirwan, "Mengukur kesiapan Kalimantan Tengah calon ibu kota baru," https://www.antaranews.com/berita/985420/mengukur-kesiapan-kalimantan-tengah-calon-ibukota-baru, 2019. [Online]. Available: https://www.antaranews.com/berita/985420/mengukurkesiapan-kalimantan-tengah-calon-ibu-kota-baru. [Accessed: 01-Jan-2020].

[2] S. Riyandi, "4 Alasan Presiden Jokowi pindahkan ibu kota ke Palangkaraya," https://www.merdeka.com/, 2017. [Online]. Available: https://www.merdeka.com/uang/4-alasanpresiden-jokowi-pindahkan-ibu-kota-ke-palangkaraya.html.

[3] C. Stefanie, "Kajian Pindah Ibu Kota ke Palangkaraya Diharap Rampung 2019," https://www.cnnindonesia.com/, 2017. [Online]. Available: https://www.cnnindonesia.com/ekonomi/20170410181157-78-206402/kajian-pindah-ibu-kotake-palangkaraya-diharap-rampung-2019. [Accessed: 16-Aug-2019].

[4] H. M. N. Darlan, Retrospektif dan Prospektif Palangka Raya Menuju Ibu Kota Negara. Yogyakarta: Pustaka Pelajar, 2017.

[5] L. J. Moleong, Metodologi Penelitian Kualitatif. Bandung: Remaja Rosdakarya, 2006.

[6] N. K. D. \& Y. S. Collin, The Sage Handbook: Qualitative Research I. Yogyakarta: Pustaka Pelajar, 2011.

[7] H. Herdiansyah, Wawancara, Observasi, dan Vocus Groups. Jakarta: PT Raja Grafindo Persada, 2015.

[8] J. W. Creswell, Research design : qualitative, quantitative, and mixed methods approaches, 4th ed. United States of America: SAGE Publications, Inc. All rights reserved. No part of this book may be rep, 2014.

[9] I. H. Suardi Lubis, Andri Suprayogi ST., MT *, "Kesesuaian Rencana Tata Ruang Wilayah (Rtrw) Dengan Penggunaan Lahan Kecamatan Gayamsari Dan Kecamatan Semarang Timur," J. Geod. Undip, vol. 2, no. 2, pp. 13-22, 2013.

[10] L. Z. and Z.-R. Peng2, "LandSys II: Agent-Based Land Use-Forecast Model with Artificial Neural Networks and Multiagent Model," J. Urban Plann. Dev., vol. 141, no. 4, 2015.

[11] I. Díaz-parra, "International Journal of Urban Sciences A back to the city movement by local government action : gentrification in Spain and Latin America," no. May, pp. 37-41, 2015.

[12] D. M. R. \& I. L. M. 1Mahasiswa Rohaya Putri Mokodongan1, "ISSN 2442-3262 Jurnal 
Perencanaan Wilayah dan Kota Definisi Tata Ruang Jurnal Perencanaan Wilayah dan Kota," vol. 6, no. 1, pp. 68-77, 2019.

[13] S. S. Epi Syahadat, "Permasalahan Penataan Ruang Kawasan Hutan Dalam Rangka Revisi Rencana Tata Ruang Wilayah Provinsi," J. Anal. Kebijak. Kehutan., vol. 9, no. 2, 2012.

[14] K. Saddhono, "Language of Coastal Communities in the Northern Coast of Central Java: Sociolinguistic Studies in Cultural Integration Maritime-Agrarian Perspective." Adv. Sci. Let. vol. 23 no. 10 pp 10054-10056, 2017 